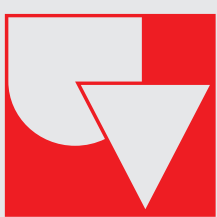

Universidad del Valle

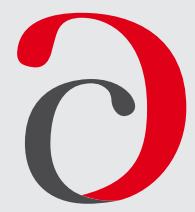

Cuadernos de Administración
Journal of Management

Print ISSN: 0120-4645 / E-ISSN: 2256-5078 / Short name: cuad.adm.

Pages: 105-117 / Vol: 36 / Issue: 66 / Jan. - Apr. 2020

Faculty of Administration Sciences / Universidad del Valle /

Cali - Colombia

\title{
Social networks and academic performance self-perception in business sciences students
}

\author{
Redes sociales y autopercepción de desempeño académico \\ en estudiantes de ciencias empresariales
}

${ }^{1}$ Eduardo Ahumada-TelloD

Professor and researcher, Coordinator of the Doctorate in Administrative Sciences at School of Accounting and Administration, Universidad Autónoma de Baja California, México. e-mail: eahumada@uabc.edu.mx

\section{${ }^{2}$ Rafael Ravina-Ripólz(D)}

Associate Professor, Department of Business Organization, Universidad de Cádiz, Cádiz, Spain e-mail: rafael.ravina@uca.es

\section{${ }^{3}$ Edgar Julián Gálvez-Albarracín(D)}

Head Professor, Department of Administration and Organizations, School of Administration Sciences Universidad del Valle, Cali, Colombia. e-mail: edgar.galvez@correounivalle.edu.co

\begin{tabular}{r}
\hline Article of Scientific and Technological Research \\
Submitted: $15 / 04 / 2019$ \\
Reviewed: 30/07/2019 \\
Accepted: 10/02/2020 \\
Thematic lines: Administration and Organizations \\
JEL classification: O33, M15, F60, I21 \\
DOI: https://doi.org/10.25100/cdea.v36i66.7761
\end{tabular}

\section{Abstract}

Considering that individuals and organizations for different activities increasingly use social networks (SN), this paper seeks to describe the level of usefulness that business sciences university students find in them, and the impact thereof on their Academic Performance self-perception (APS). The results show that in both Mexico and Spain, the target audience considers that SN are useful for academic topics, this being more noticeable in the first country; Likewise, APS is better in Mexican students. On the other hand, using linear regressions as a statistical technique, in both nations was found that the more usefulness obtained from the SN, the higher students' APS, which turned out more noticeable in the Spanish case. In today's world, where thanks to information and communication technologies (ICTs), there are high possibilities for interconnection between people and organizations, these findings are of interest to universities, government bodies and companies because they all offer products and/or services to a public who needs to feel that the former know more and learn about them better, for which SN become a current and versatile tool for dissemination.

Keywords: Information and Communication Technologies, Social networks, University education, Academic performance, Interculturality.

\footnotetext{
1 Computer Engineer, Universidad Autónoma de Baja California, México, Doctor in Administrative Sciences, Universidad Autónoma de Baja California, México, Doctor in Education, Universidad Iberoamericana, México.

2 Degree in economics and business, Doctor in History, Universidad de Cádiz, Spain.

3 Business Administrator, Universidad del Valle, Colombia, Doctor in Business Administration and Management, Universidad Politécnica de Cartagena, Spain.
} 


\section{Resumen}

Teniendo en cuenta que las redes sociales (RS) son cada vez más usadas por las personas y las organizaciones para diferentes actividades, este trabajo busca describir el nivel de utilidad que encuentran en ellas los estudiantes universitarios de ciencias empresariales, y el impacto de esto sobre su autopercepción de desempeño académico (ADA). Los resultados muestran que tanto en México como en España el público objetivo considera que las RS son útiles para temas académicos, siendo ello más notable en el primer país; así mismo que la ADA es mejor en los estudiantes mexicanos. Por otra parte, utilizando regresiones lineales como técnica estadística se encontró en ambas naciones que a mayor utilidad obtenida en las RS los alumnos alcanzan mayor ADA, siendo más notorio esto en el caso español. En el mundo actual donde gracias a las tecnologías de información y comunicación (TIC), hay altas posibilidades de interconexión entre personas y organizaciones, estos hallazgos son de interés para las universidades, los entes gubernamentales y las empresas, pues todos ofrecen productos y/o servicios a un público universitario que necesita sentir que conoce más y aprende mejor acerca de ellos, para lo cual las RS se constituyen en una herramienta actual y versátil para su divulgación.

Palabras clave: Tecnologías de la Información y Comunicación, Redes sociales, Educación universitaria, Desempeño académico, Interculturalidad.

\section{Introduction}

Currently, the Internet is widely used by a large share of the world population. In the case of Mexico, its use rose from $20.2 \%$ in 2006 to $82.7 \%$ in 2018, mostly by young people between the ages of 25 and 34 (22\% of the total users), followed by those between 18 and 24 years old (18\%), segments where precisely potentially university individuals fall (AMIPCI, 2019). In that country by 2015, $70 \%$ of Internet users were registered in at least one SN and about $60 \%$ of them logged in on a daily basis (Domínguez and López, 2015), and $82 \%$ of Internet users reported to do so to access them by 2019, and this purpose was the main reason to access the internet (AMIPPCI, 2019).

For its part, according to the report "Socio-demographic netizens profile" in Spain, the use of the Internet is increasingly entrenched, and so much so that $87.3 \%$ of the national population reported using it at least once in the year in 2018, and $72.1 \%$ said to using it on a daily basis, and those with university studies turned out to be the most assiduous users (97.4\% of them). Likewise, young people aged 16 to 24 make up $11.7 \%$ of the total number of netizens, those aged 25 to $3415.3 \%$ and those aged 35 to 44 account for $21.6 \%$. In turn, more than $95 \%$ of people between the ages of 16 and 34, students and individuals with completed higher education studies, log in on a daily basis to the Network (Urueña, Seco, Castro, and Cárdenas, 2019).

In this context, SNs have become key tools for communication in different social areas including education (Santoveña-Casal and Bernal-Bravo, 2019), since they can promote and facilitate collaborative learning and access to global information. This is how in the case of university students, ICTs offer the necessary platforms for SNs to become integrated as didactic strategies in the different training programs (Aranda, Creus and Sánchez-Navarro, 2014; Cabero, Del Prete and Arancibia, 2019; Hermann-Acosta, Apolo, and Molano-Camargo, 2019).

Something different happens within companies, for consumers increasingly prefer, and even demand, to communicate with them through ICT tools and preferably SNs (Rodríguez and Chapis, 2019), which is exploited by these organizations to capture information that is processed on digital platforms and then becomes useful in decision-making (García, 2017).

On the other hand, Álvarez, Sandoval, Saker, and Moreno (2017) point out that education is a continuous process that boosts the human being to achieve greater integrality, and in connection thereto authors such as Paso-Niebla and Hernández-Guzmán (2007) and Del Valle and Urquijo (2015) conceive that Academic Performance (AP) is the level at which an individual achieves the knowledge and skills objectives established for a given training program, which in turn influences the well-being and happiness levels of that person (Paschoal, Torres, and Porto, 2010; Posada and Aguilar, 2012; Moreno and Marrero, 2015).

Studies about the effect on APS of using SNs focus on national or local cases, and fail to include recent comparisons between countries with mutual mobility of students and professionals, which is useful for university 
organizations and those that provide them with products and services. In this sense, this research work seeks to provide information that contributes to filling the aforementioned gap, wherefore the following research questions are posited: what is the usefulness level that administrative sciences students in Mexico and Spain find in SNs? How is the APS of these students? How does the usefulness found in SNs influence the APS of these university students? What differences are there between the results for each group of students and how could they be explained?

Firstly, this paper presents the corresponding theoretical support that allows us to propose the hypotheses to be contrasted throughout the work; then the methodology used is described and the descriptive and correlational results obtained are displayed and discussed thereafter in order to finally include the conclusions, implications, limitations and future lines derived from the research.

\section{Theoretical framework}

\subsection{Information and communication technologies, social networks and training}

The proper handling of ICTs has become an important competence for any person's performance, whether in his social, academic or work environment, which is why higher education institutions and other organizations have had to incorporate them in their training processes (Domínguez and Ló fish, 2015).

On the other hand, virtual SNs are relationship systems established between acquaintances or friends, called contacts, that interrelate through electronic platforms associated with the Internet (Leal, García, Estrada, and Cabecero, 2018), examples whereof are Facebook, Twitter, WhatsApp and YouTube, which have created a space to develop interpersonal and interorganizational communication (Medina, Romero, and González, 2011; Farías, 2016; Crovi and López, 2014), through which information about the different activities carried out and materials flow (Scuotto, Del Giudice, Peruta, and Tarba, 2017).
The above is the reason for the current boom of models, strategies and methodologies with a common and fundamental factor: the Internet. Some are fully based on electronic media (e Learning) and others that combine presentiality with virtuality (BlendedLearning or B-Learning), and both require facilitators and apprentices, and a specialized technological infrastructure prepared appropriately (Ponce-Rojo, HernándezVega, Hernández-Contreras, and FernándezRodríguez, 2012).

This trend is so strong that previous studies haven shown that university students increasingly use chats to share information related to their academic education (Islas and Carranza, 2011; Celis and Torres, 2012; Isaak, 2014), and that the non-use or prohibition of SNs during in-class activities by teachers, may discourage students (Medina et al. , 2011; Ortega Barba and Banderas Campero, 2011; and Torres, 2012).

Nevertheless, it cannot be denied that improper use of SNs generates conflicts in any environment whether it is work, studying or mere friendship, especially when associated with addictive behaviors (Muhingi, Mutavi, Kokonya, Simiyu, Musungu, Obondo, and Kuria, 2015; Stankovska, Angelkovska, and Grncarovska, 2016; Turel and Qahri-Saremi, 2016; Dias, Cadime, del Castillo-López, García-Castillo, and García del Castillo, 2018; Pedrero Pérez, et. al., 2017), which is why the relevant authority figure must regulate or approach the issue appropriately so that this happens as little as possible (Marín, Sampedro, and Muñoz, 2015; Wright, 2018; Yan, Sallam, and Yinghua, 2019).

Thus, SNs become a fundamental element for organizational communication and collaboration among members of working groups, as well as a relevant factor to enhance the impact of ICTs in the search for the development of the organization and the individuals that make up it.

\subsection{Academic performance and social networks}

Nowadays, universities are aware that they must prepare their students and future graduates to work in a social and work 
environment where cooperation is imperative (García and Carmona, 2014), and the Internet is strongly integrated into different activities; and for this purpose, they establish strategies that integrate the available ICT platforms and SNs, also seeking to facilitate better academic performance in the students thanks to greater interaction with their professors, peers and with large and easily accessible databases (Ayala-Pérez, 2015).

In this sense, and because SNs influence the behavior of young people and can therefore benefit their academic results (Santos, 2010; Molina Campoverde, Toledo Naranjo, and Peña Castro, 2014; Giunchiglia, Zeni, Gobbi, Bignotti, and Bison 2018), they are now fundamental to the strengthening of their training process (Alwagait, Shahzad, and Alim, 2015).

Furthermore, several studies indicate that SNs can positively influence creativity and cognitive development in university students to the point that they even suggest professors activities involving such technologies (Gómez, Roses, and Farias, 2012), thereby strengthening often communication networks in a virtual or semi-virtual environment that promotes the use of ICTs in new spaces for knowledge transferring (Van Waes, De Maeyer, Moolenaar, Van Petegem, and Van den Bossche, 2018).

From the above theory and the previous works described the following hypotheses can be proposed, which guide this research:

H1: The greater the usefulness administrative science students in Mexico find in SNs, the better their APS will be.

H2: The greater the usefulness administrative science students in Spain find in SNs, the better their APS will be.

H3: Due to cultural particularities and in the respective educational models, there are differences between the two population groups observed in relationship under study.

\section{Methodology}

This work, which is cross-sectional, nonexperimental, quantitative and correlational, collected the data through a survey structured from available literature, and applied through a Web tool. The target population in Mexico was active students in the 20162017 period at the School of Accounting and Administration of the Universidad Autónoma de Baja California (UABC per its acronym in Spanish), and in Spain students from the School of Economic and Business Sciences of the Universidad de Cádiz (UC per its acronym in Spanish) during the year 2018. The sample was collected randomly and shaped as shown in Table 1.

\begin{tabular}{|c|c|c|}
\hline & UABC & UC \\
\hline Population (N) & $\begin{array}{c}3900 \\
\text { Students (\%) }\end{array}$ & $\begin{array}{c}8559 \\
\text { Students (\%) }\end{array}$ \\
\hline Source of the population & FCA & FCA \\
\hline $\mathrm{P}$ & 50.00 & 50.00 \\
\hline Q & 50.00 & 50.00 \\
\hline Permissible Error (E) & 9.68 & 8.00 \\
\hline Z & 1.96 & 1.96 \\
\hline Confidence Level (K) & 95.00 & 95.00 \\
\hline Sample Size $(n)=$ & 100 & 100 \\
\hline $\begin{array}{c}\mathrm{E}=2 * \operatorname{root}(\mathrm{N}-\mathrm{n}) /(\mathrm{n}-1) * \\
\quad\left(\mathrm{p}^{*} \mathrm{q} / \mathrm{n}\right)=\end{array}$ & 9.88 & 8.16 \\
\hline \multicolumn{3}{|c|}{$\begin{array}{c}\text { Source: Authors' own elaboration based on the data } \\
\text { gathered in the research. }\end{array}$} \\
\hline
\end{tabular}

\subsection{Measuring scales}

To measure students' perception and SNs use, the scale shown in Table 2 was used, which is an adapted version based on the theoretical review of the constructs that make up the structure of the research, which was previously carried out by Ahumada-Tello, 2017 and Ahumada-Tello, Ravina-Ripoll, and Hernández de Velasco, 2018. The Cronbach Alpha indicator shows that the instrument effectively measures the phenomenon under observation because, according to Nunnally (1967), when this value is 0.600 or higher, it is considered valid for social studies. 
Table 2. Social networks perception and use scale

Please rate your degree of disagreement or agreement with each of the following observations regarding your participation and the usefulness you find in SNs; use a scale from 1 to 7, where 1 means totally disagree and 7 fully agree:

1. I like to engage in social networks.

2. I feel more educated due to using social networks.

3. Social networks are a part of my life.

4. For me, it is essential to review my social networks.

5. My decision to travel and accommodation on vacation is influenced by accessing social networks.

6. I like to appear in videos or photographs on social networks.

7. I have more friends on social networks than I do in person.

8. In social networks, I find help in work or academic situations.

9. In social networks, I find help in personal situations.

10. Social networks are a valuable source of information.

11. I accept all friendships that approach me through social networks.

12. Social networks improve my learning of the world.

13. Social networks improve my academic learning.

14. Social networks make me happy

15. Social networks make those around me happy.

16. Social networks increase my knowledge, skills and abilities.

17. Social networks increase my ability to interact with other people.

18. Social networks increase my tolerance and acceptance of differences between people.

Cronbach's alpha for: 1) UABC data: 0.892; 2) UC data: 0.901

Source: Authors' own elaboration from the adapted version of Ahumada-Tello (2017) and Ahumada-Tello et al., 2018.

Table 3. Perception of academic performance scale

Please rate your degree of disagreement or agreement with each of the following observations regarding your academic performance perception (APS); use a scale from 1 to 7 , where 1 means fully disagree and 7 fully agree:

1. My academic results are excellent.

2. The learning I have gained meets the objectives of my studies.

3. I feel competent to perform the functions that I have been taught in the course of my studies.

4. I find practical applications for everything I've learned.

5. I am among the best students in my classes.

6. I am highly competitive in my classes and I tend to look for the highest grade.

7. I have a good relationship with my classmates.

8. I have a good relationship with my teachers.

Cronbach's alpha for: 1) UABC data: 0.807 ; 2) UC data: 0.814

Source: Authors' own elaboration from the adapted version of Ahumada-Tello (2017); Ahumada-Tello et al., 2018.

For its part, Table 3 presents the scale with which the students surveyed measured ASP. Similarly, in this case it corresponds to an adaptation based on the theoretical review of the constructs that make up the structure of the research ( Ahumada-Tello, 2017; A humada-Tello, et al. , 2018). Cronbach's Alpha confirm that the instrument is ideal for measuring the observed phenomenon.

\section{Presentation and discussion of results}

\subsection{Descriptive results}

Table 4 allows us to know the means and standard deviations for the answers to each question regarding the usefulness found in 
Table 4. Describers of the usefulness found in SNs

\begin{tabular}{|c|c|c|c|c|c|}
\hline \multirow[t]{2}{*}{ Question } & \multicolumn{2}{|c|}{ UABC } & \multicolumn{2}{|c|}{ UC } & \multirow[b]{2}{*}{$\begin{array}{c}\text { Means } \\
\text { difference }\end{array}$} \\
\hline & Mean & $\begin{array}{l}\text { Standard } \\
\text { Deviation }\end{array}$ & Mean & $\begin{array}{l}\text { Standard } \\
\text { Deviation }\end{array}$ & \\
\hline I like to participate in social networks & 4.89 & 1.61 & 4.72 & 1.67 & Not significant \\
\hline I feel more educated due to using social networks & 3.02 & 1.52 & 2.84 & 1.56 & Not Significant \\
\hline Social networks are a part of my life & 4.05 & 1.95 & 4.14 & 1.71 & Not Significant \\
\hline For me it is essential to review my social networks & 3.68 & 1.68 & 3.61 & 1.79 & Not Significant \\
\hline $\begin{array}{l}\text { My decision to travel and accommodation on } \\
\text { vacation is influenced by accessing social networks }\end{array}$ & 3.40 & 1.92 & 2.51 & 1.59 & Significant \\
\hline $\begin{array}{l}\text { I like to appear in videos or photographs on social } \\
\text { networks }\end{array}$ & 3.35 & 1.99 & 3.39 & 1.78 & Not Significant \\
\hline $\begin{array}{l}\text { I have more friends on social networks than I do in } \\
\text { person }\end{array}$ & 3.32 & 2.08 & 3.27 & 2.13 & Not Significant \\
\hline $\begin{array}{l}\text { In social networks, I find help in work or academic } \\
\text { situations }\end{array}$ & 4.35 & 1.71 & 3.76 & 1.62 & Not Significant \\
\hline In social networks, I find help in personal situations & 2.90 & 1.83 & 2.91 & 1.66 & Not Significant \\
\hline Social networks are a valuable source of information & 4.62 & 1.66 & 4.72 & 1.58 & Not Significant \\
\hline $\begin{array}{l}\text { I accept all friendships that approach me through } \\
\text { social networks }\end{array}$ & 2.46 & 1.78 & 1.88 & 1.55 & Significant \\
\hline Social networks improve my learning of the world & 3.67 & 1.68 & 3.78 & 1.67 & Not Significant \\
\hline Social networks improve my academic learning & 3.32 & 1.63 & 3.31 & 1.58 & Not Significant \\
\hline Social networks make me happy & 3.51 & 1.57 & 3.59 & 1.58 & Not Significant \\
\hline Social networks make those around me happy & 4.20 & 1.48 & 4.19 & 1.58 & Not Significant \\
\hline $\begin{array}{l}\text { Social networks increase my knowledge, skills and } \\
\text { abilities }\end{array}$ & 3.37 & 1.61 & 3.70 & 1.59 & Not Significant \\
\hline $\begin{array}{l}\text { Social networks increase my ability to interact with } \\
\text { other people }\end{array}$ & 3.90 & 1.60 & 3.95 & 1.79 & Not Significant \\
\hline $\begin{array}{l}\text { Social networks increase my tolerance and } \\
\text { acceptance of differences between people }\end{array}$ & 4.05 & 1.65 & 4.08 & 1.83 & Not Significant \\
\hline Total usefulness found in SNs & 3.67 & 1.02 & 3.58 & 1.06 & Not Significant \\
\hline Source: Authors' own elabor & on bas & the data $g$ & ed in $\mathrm{t}$ & earch. & \\
\hline
\end{tabular}

the SNs, as well as the significance analysis of the corresponding differences in the means, for which the $\mathrm{T}$ test for independent samples was applied.

For the case of the UABC, we found that the mean of the total usefulness of SNs is 3.67, which is relatively low considering that we used a 7-point scale, so results falling between 3 and 4 denote doubt about the subject analyzed. Regarding the different specific questions asked, it is noted that the ones with the highest scores are "I like to participate in SNs" (4.89), "SNs are a valuable source of information" (4.62) and "In SNs I find help in work or academic situations" (4.35); for their part, the ones with the lowest score were: "I accept all the friendships that approach me through social networks" (2.46) and "in social networks, I find help in personal situations" (2.90). These results confirm the usefulness that social SNs offers to these people for academic topics.

The mean of the mean of the total is 3.58 with regards to UC and the total "usefulness found in SNs", which is also moderately low considering above description. Again, it is observed that those with higher scores are I like to participate in $S N s$ and $S N s$ are a valuable source of information (both 4.72), and "social networks make those around me happy" (4.19). On the other hand, the lowest scores were "I accept all the friendships that approach me through social networks" (1.88) and "Mydecision to travel and accommodation on vacation is influenced by accessing social networks" (2.51). These results indicate that Spanish students, like Mexicans, value the information they find in SNs and that they 


\begin{tabular}{|c|c|c|c|c|c|}
\hline \multicolumn{6}{|c|}{ Table 5. Describers of students' ASP } \\
\hline \multirow[t]{2}{*}{ Question } & \multicolumn{2}{|c|}{ UABC } & \multicolumn{2}{|c|}{ UC } & \multirow[b]{2}{*}{$\begin{array}{c}\text { Means } \\
\text { difference }\end{array}$} \\
\hline & Mean & $\begin{array}{l}\text { Standard } \\
\text { Deviation }\end{array}$ & Mean & $\begin{array}{l}\text { Standard } \\
\text { Deviation }\end{array}$ & \\
\hline My academic results are excellent. & 5.40 & 0.91 & 4.38 & 1.30 & Significant \\
\hline $\begin{array}{l}\text { The learning I have gained meets the objectives of } \\
\text { my studies. }\end{array}$ & 5.41 & 1.01 & 4.65 & 1.34 & Significant \\
\hline $\begin{array}{l}\text { I feel competent to perform the functions that I have } \\
\text { been taught in the course of my studies. }\end{array}$ & 5.56 & 1.09 & 4.79 & 1.32 & Not Significant \\
\hline $\begin{array}{l}\text { I find practical applications for everything I've } \\
\text { learned. }\end{array}$ & 5.50 & 0.96 & 4.18 & 1.45 & Significant \\
\hline I am among the best students in my classes. & 4.94 & 1.40 & 3.72 & 1.69 & Significant \\
\hline $\begin{array}{l}\text { I am highly competitive in my classes and I tend to } \\
\text { look for the highest grade. }\end{array}$ & 5.03 & 1.50 & 4.21 & 1.70 & Not Significant \\
\hline I have a good relationship with my classmates. & 5.95 & 1.11 & 5.78 & 1.03 & Not Significant \\
\hline I have a good relationship with my teachers. & 5.87 & 1.05 & 5.51 & 1.10 & Not Significant \\
\hline TOTAL ASP & 5.46 & 0.75 & 4.65 & 0.91 & Significant \\
\hline
\end{tabular}

find it useful to solve everyday problems, which may include work or personal ones.

When comparing the means of UABC versus those of UC, the "total perceived usefulness in SNs" is observed higher in the first university as well as in 7 of the 18 items consulted, while the score is higher in UC for the remaining 11. Notwithstanding the foregoing, it should be noted that only statistical significance was found for the differences in means of those of the Items "my decision of travel and accommodation on vacation is influenced by access to the $S N s^{\prime \prime}$ (3.40 for UABC versus 2.51 in UC) and in "I accept all friendships that approach me through SNs" (2.46 in UABC and 1.88 in UC), which indicates in the first case that Mexican students use these tools more to search for new travel experiences and at the same time that they are more open but less careful to choose their contacts in them.

As for the APS of the students approached, Table 5 shows that for those in the UABC the "mean of the total" is 5.46, which is relatively high on the 7-point scale used, and the most outstanding performance indicators in their order are: "having good relations with colleagues" with 5.95, "having good relations with teachers" with 5.87 and "feeling competent to perform the functions they have taught me in my classes" (5.56) and those with lowest scores: "being among the best students" with 4.94, followed by "being highly competitive" with 5.03.

In the case of UC, the average total ASP was 4.65 and the highest indicators are the same as in the other University, i.e., having "good relations with colleagues" with 5.78 followed by "good relations with teachers". (5.51) and "feeling competent to perform the functions that I have been taught in my classes" (4.79); in turn, "being among the best students of my classes" (3.72) and "I am highly competitive in my classes and I tend to pursue the highest grade" with 4.21 hold the lowest scores.

When comparing ASP means between the two groups of students, all cases are observed higher in UABC, which means that they feel more at ease with their academic performance than those at UC. This could be due to higher levels of demand in Spain, which will make it more difficult for its students to get satisfactory results and/or their expectations of ASP to be higher. At the same time, it is important to point out that the means difference was significant for half of the factors evaluated as well as for the "total ASP", which highlights the greater usefulness that Mexican students find in the knowledge received, as well as their greater perception of preparedness for the functions they must perform in business activities since these are the purpose of their training. 


\subsection{Correlational results}

Table 6 shows the results of the ordinary least squares (OLS) linear regressions applied to determine the impact of the "total usefulness found in SNs" on the ASP of the two groups of students addressed. First of all, it should be noted that the variables analyzed respectively were tested for normal behavior and to be free of collinearity or dependence on their data beforehand, which the values of the VIF and the Durbin Watson statistics attest to; likewise, the positive and significant value of $\mathrm{F}(1,747 *$ and $18,087 * * *$ respectively) show that the models used are vested with overall validity.

\begin{tabular}{|l|c|c|}
\hline \multicolumn{3}{|c|}{ Table 6. Effect of the usefulness found } \\
in SNs on ASP \\
\hline & ASP at UABC & ASP at UC \\
\hline Total SNs usefulness & $0.167 *$ & $0.352^{* * *}$ \\
\hline $\mathrm{t}$ & $1.322^{*}$ & $14.262^{* * *}$ \\
\hline $\mathrm{F}$ & $1.747^{*}$ & $18.087 * * *$ \\
\hline Highest VIF & 1.000 & 1.000 \\
\hline Durbin Watson & 1.799 & 1.679 \\
\hline R2 adjusted & 0.012 & 0.124 \\
\hline *significance at 90\%, ** significance at 95**, ***significance \\
at 99\% \\
\hline \multicolumn{3}{|c|}{ Source: Authors' own elaboration based on the data } \\
gathered in the research. \\
\hline
\end{tabular}

First of all, it can be seen that the "usefulness found in SNs" influences positively and significantly the ASP $(0.167 *$ in the first case and $0.352 * * *$ for the second) in both UABC and UC students, and the first two hypotheses can be considered accepted with these results, which proposed that the better perception of usefulness found in SNs, the better the ASP would be in the students of both universities.

When comparing the value of betas, the relationship studied is observed higher and more significant in the case of UC $\left(0.352^{* * *}\right)$ than in UABC $(0.167 *)$, thus making it possible to accept the third hypothesis of the work. This also means that while in the first university a one-point increase in the usefulness of SNs generates a 0.352 points increase in the ASP of students, and in the second institution the same one-point increase drives up the of school performance perception 0.167 points. In turn, the value of $\mathrm{R}^{2}$ indicates that the independent variable explains $12.4 \%$ of the variation in the dependent on in UC, while it explains $1.2 \%$ in the Mexican university.

The fact that in Spanish universities there is greater integration and dissemination of SNs to disseminate academically useful explains the differences in the betas and $\mathrm{R}^{2}$. In the same way, from the data and information they access the inference can be drawn that Spanish students make a more efficient use of ICTs in their professional training, which can also be related to the already indicated higher academic demand in the European educational model. These results are consistent with the findings and postulates of Ayala-Pérez (2015) regarding the benefits that the good use of SNs brings about for training and ASP.

On the other hand, Graphs 1 and 2 display the dispersion of the cases included in the linear regressions applied for students in Mexico and Spain respectively, which shows that the data is not far away from the resulting line for the two samples, which is important to draw conclusions with a sound level of confidence.

\section{Conclusions, implications, limitations and future work}

Below are the main conclusions and implications of this research that aimed to describe and compare the usefulness business sciences students in Mexico and Spain find in SNs and the effect of the same on their ASP.

Despite the moderate perception of SNS total usefulness manifested by the students involved, future professionals are observed to find valuable information for their academic activities in these communication tools, which also promotes their happiness and facilitates their relationships and interpersonal tolerance, which is clearly important for their current and future educational and professional performance, which is closely tied to companies due to their area of knowledge. These findings are of great value for university organizations because it shows them SNs are an important ally to make their students feel better trained and with better performance, which could be 
Graph 1. P-P for the Effect of Usefulness Found in SNs on ASP in Mexico

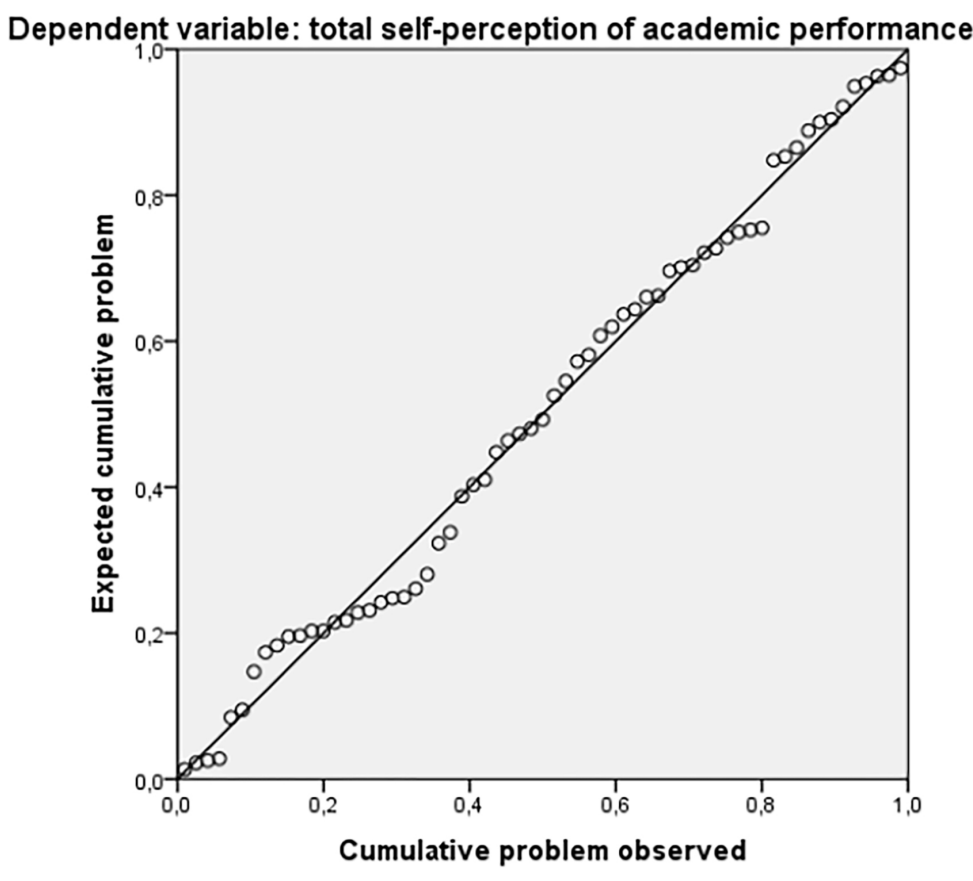

Source: Authors' own elaboration based on the data gathered in the research.

Graph 2. P-P for the Effect of Usefulness Found in SNs on ASP in Spain

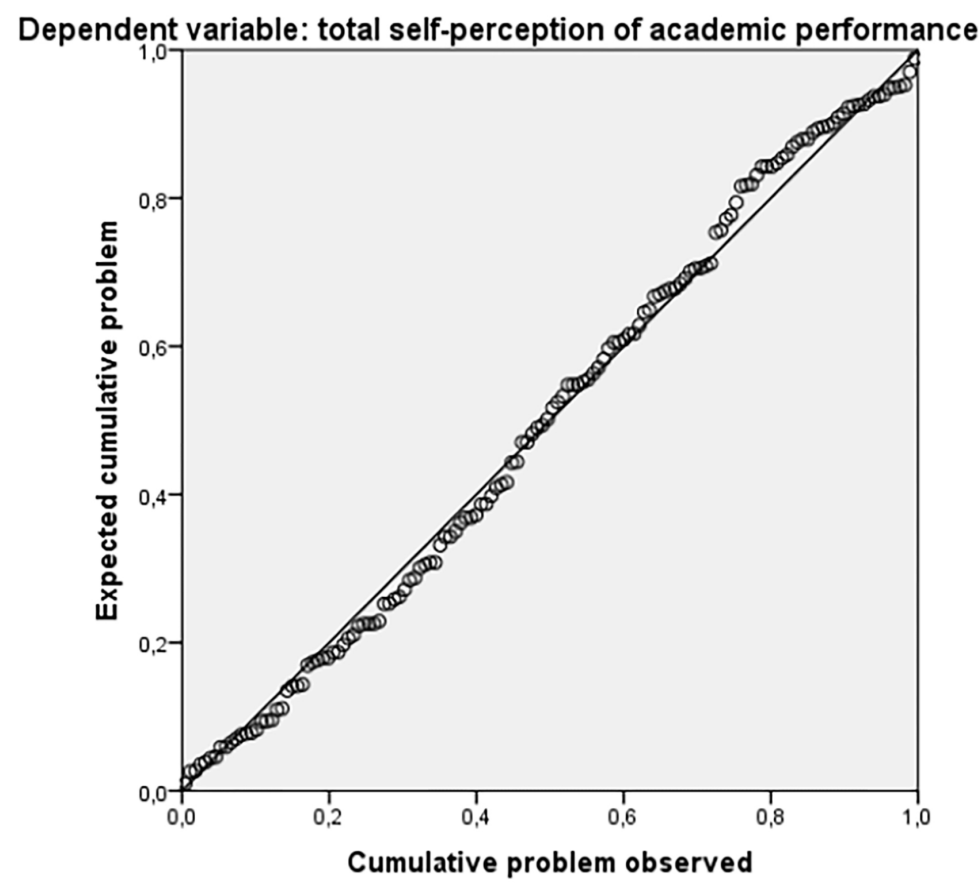

Source: Authors' own elaboration based on the data gathered in the research. 
seized to disseminate and use their different services and processes, both academically and administratively.

Significant differences in the ASP between the two population groups addressed leads to opportunities to learn from possible best practices, not only with regard to the demand levels of each education system, but also in connection to the strategies applied to make students feel more satisfied and better trained. This obviously bears important implications for the success of the training processes to be undertaken, and for university organizations to apply in a practical and consequent manner what has been learned.

The usefulness of SNs perception effect on $A S P$ was possible to confirm it as positive and significant for both groups, which attests to widespread use among students and in turn entails the corresponding impact on ASP. This implies that universities and companies can and should also continue to promote the organized use of these ICT tools in their training processes, as a current and relevant stimulus for student and employee performance, for they observe innate familiarity in the performance of their activities through the use of ICTs.

Among the limitations of the work and future lines of research, we are able to point out the following: having included the question I accept all the friendships that approach me through social networks could have biased downward the average of the total usefulness found in SNs, wherefore future works will consider suppressing it or replacing it with another matter of interest. The fact that the sample of students was taken from only two universities and in only two areas of knowledge relatively restricts extrapolating the results to the entire university population. Therefore, it would be important to further extend the sample to other educational institutions and to more majors and countries. Lastly, it should be noted that questions about SNs or tools specially designed for educational purposes such as virtual campuses, Kahoot or Edpuzel were not included; new research could assess their effect on ASP.

\section{Conflict of interest}

The authors declare no conflict of interest.

\section{Source of Financing}

The authors declare that this research did not received funding or sponsorship.

\section{References}

Ahumada-Tello, E. (2017). Percepción de competitividad personal. Un estudio desde la perspectiva de la felicidad, el bienestar y la educación en egresados universitarios. Revista de Estudios Empresariales Segunda época, (1), 34-54. https://doi.org/10.17561/ree.v0i1.3187

Ahumada-Tello, E., Ravina-Ripoll, R., y Hernández de Velasco, J. (2018). El rol de las redes digitales en el desempeño académico y en la percepción de felicidad social en estudiantes universitarios en Baja California. Claves Para Un Desarrollo Sostenible: La Creatividad y El" Happiness Management" Como Portafolio de La Innovación Tecnológica, Empresarial y Marketing Social (pp. 99-116). Madrid, España: Editorial Comares. Recuperado de https://dialnet.unirioja.es/ servlet/articulo?codigo $=6575027$

Alwagait, E., Shahzad, B., \& Alim, S. (2015). Impact of social media usage on students academic performance in Saudi Arabia. Computers in Human Behavior, 51(part B). https://doi. org/10.1016/j.chb.2014.09.028

Álvarez, A., Sandoval, O., Saker, J., y Moreno, G. (2017). Competencias Ciudadanas para la formación integral en educación superior. Barranquilla, Colombia: Universidad de la Costa. Recuperado de http://repositorio. cuc.edu.co/bitstream/handle/11323/1169/ Competencias\%20ciudadanas. ACCD2E935DD7952970A5A?sequence=1

Asociación Mexicana de la Industria Publicitaria y Comercial en Internet, A.C. ( AMIPCI). (2019). Estudio sobre los hábitos de los usuarios de Internet en México 2019. Asociación Mexicana de Internet. Recuperado de https://www.asociaciondeinternet.mx/es/ component/remository/func-startdown/97/ lang,es-es/?Itemid=

Aranda, D., Creus, A., Sánchez-Navarro, J. (Eds.). (2014). Educación, medios digitales y cultura de la participación. Educatio Siglo 
XXI, 32(2), 355-358. https://digitum.um.es/ digitum/bitstream/10201/42013/1/Aranda,\%20 D. \%20Creus, \%20A.\%20y\%20S\%c3\%a1nchezNavarro,\%20J.\%20(eds.)\%20(2013).pdf

Ayala-Pérez, T. C. (2015). Redes sociales e hiperconectividad en Futuros profesores de la generación digital. Ciencia, Docencia y Tecnología, 25 (51), 244-270. Recuperado de http://www.pcient.uner.edu.ar/cdyt/article/ view/58

Cabero, J., Del Prete, A., y Arancibia, M. L. M. (2019). Percepciones de estudiantes universitarios chilenos sobre uso de redes sociales y trabajo colaborativo. Revista Iberoamericana de Educación a Distancia, 22(2). http://dx.doi.org/10.5944/ried.22.2.22847

Caso-Niebla, J., y Hernández-Guzmán, L. (2007). Variables que inciden en el rendimiento académico de adolescentes mexicanos. Revista latinoamericana de psicología, 39(3), 487501. Recuperado de https://psycnet.apa.org/ record/2007-19724-004

Celis, A. B. y Torres, E. (2012, octubre) Comunicación oral y retroalimentación a través de redes sociales: Facebook como soporte de evaluación de aprendizajes. Memoria electrónica del 28 Simposio Internacional de la Sociedad Mexicana de Computación en la Educación (SOMECE), México. https:// prezi.com/zqdpxlje3afk/comunicacion-oral-yretroalimentacion-a-traves-de-redes-socialesfacebook-como-soporte-de-evaluacion-deaprendizajes/

Crovi, D., y López, R. (2014, agosto). Interacción en Redes Sociales Digitales. Jóvenes Estudiantes y trabajadores describen sus prácticas en red. XII Congreso de la Asociación Latinoamericana de Investigadores de la Comunicación, ALAIC, Lima, Perú. http://congreso.pucp.edu.pe/ alaic2014/wp-content/uploads/2013/09/GT4Delia-Crovi-y-Roc\%C3\%ADo-L\%C3\%B3pezGT4.pdf

Del Valle, M., y Urquijo, S. (2015). Relaciones de las estrategias de codificación mnésica y la capacidad de aprendizaje con el desempeño académico de estudiantes universitarios. Psicología Educativa, 21(1), 27-37. https://doi. org/10.1016/j.pse.2015.02.004

Dias, P. C., Cadime, I., del Castillo-López, A. G., García-Castillo, F., y García del Castillo, J. A. (2018). Uso abusivo de Facebook entre universitarios portugueses: contribución a la adaptación de la Bergen Facebook Addiction. Health \& Addictions, 18(1), 131-139. https://doi. org/10.21134/haaj.v18i1.377
Domínguez, F., y López, R. (2015). Uso de las redes sociales digitales entre los jóvenes universitarios en México. Hacia la construcción de un estado del conocimiento (2004-2014). Revista de Comunicación, 14, 4869. Recuperado de https://dialnet.unirioja.es/ servlet/articulo? codigo $=5223798$

Farías, A. (2016). Jóvenes universitarios y la formación de la ciudadanía a través de las redes sociales. Comunicación Papers, 5(10). 9-25. http://dx.doi.org/10.33115/udg bib/ cp.v5i10.22033

García, P. M. (2017). Impacto de las Redes Sociales y las Tecnologías Smart sobre la actividad económica y empresarial (Tesis doctoral). Facultad de Ciencias Económicas y Empresariales, Universidad de Cantabria, Santander, España. Recuperado de https:/l repositorio.unican.es/xmlui/bitstream/ handle/10902/11368/Tesis\%20PMCG. pdf? sequence $=1$ \&isAllowed $=\mathrm{y}$

García G., T., y Carmona, F. (2014). Profesor y alumnado conectados en una red pública compartida. Revista de Investigación Educativa, 32(2), 463-478. http://dx.doi.org/10.6018/ rie.32.2.171801

Giunchiglia, F., Zeni, M., Gobbi, E., Bignotti, E., \& Bison, I. (2018). Mobile social media usage and academic performance. Computers in Human Behavior, 82, 177-185. https://doi.org/https://doi. org/10.1016/j.chb.2017.12.041

Gómez, M., Roses, S., y Farias, P. (2012). El uso académico de las redes sociales en universitarios. Comunicar, 19(38), 131-138. http://dx.doi.org/10.3916/C38-2012-03-04

Hermann-Acosta, A., Polo, D., y Molano-Camargo, M (2019). Reflexiones y Perspectivas sobre los Usos de las Redes Sociales en Educación. Un Estudio de Caso en Quito-Ecuador. Información tecnológica, 30(1), 215-224. http://dx.doi. org/10.4067/S0718-07642019000100215

Isaak, F. (2014, junio). Propuesta de Estrategia Docente: El uso de Facebook como espacio para promover el trabajo colaborativo (T.C.) fuera del aula, en la licenciatura de Psicología Educativa de la Universidad Pedagógica Nacional. Memoria electrónica del XXVI Encuentro Nacional de Academia Mexicana de Investigadores en Comunicación (AMIC). San Luis Potosí, México.

Islas, C., y Carranza, M. (2011). Uso de las redes sociales como estrategias de aprendizaje ¿Transformación educativa? Revista Apertura, 3(2), 6-15. Recuperado de http://www.udgvirtual. udg.mx/apertura/index.php/apertura/article/ view/198/213 
Leal, F., García, M., Estrada, P., y Cabecero J. (2018). Uso de las redes sociales virtuales por los estudiantes de la UAT. UTE. Revista de Ciències de l'Educació, (1), 32-42. https://doi. org/10.17345/ute.2018.1

Marín, V., Sampedro, B. E., y Muñoz, J. M. (2015). ¿Son adictos a las redes sociales los estudiantes universitarios? Revista Complutense de Educación, 26(1), 233-251. http://dx.doi. org/10.5209/rev RCED.2015.v26.46659

Medina, G. L., Romero, G. R., y González, C. P, (2011, noviembre). Regresando a lo básico: un estudio sobre el potencial didáctico de twitter en educación superior. XI Congreso Nacional de Investigación Educativa. UNAM, Ciudad Universitaria, Ciudad de México, México. Recuperado de http://www.comie.org. $\mathrm{mx} /$ congreso/memoriaelectronica/v11/docs/ area 07/0877.pdf

Molina Campoverde, G. L., Toledo Naranjo, R. K., y Peña Castro, G. (2014). Las redes sociales y su influencia en el comportamiento de los adolescentes. Estudio a realizarse en cuatro colegios de la ciudad de Cuenca en los alumnos de primer año de bachillerato. Recuperado de http://dspace.uazuay.edu.ec/handle/datos/3659

Moreno, Y., y Marrero, R. (2015). Optimismo y autoestima como predictores de bienestar personal: Diferencias de género. Revista Mexicana de Psicología, 32(1) 27-36. Recuperado de https://www.redalyc.org/ articulo.oa? $\mathrm{id}=243045363004$

Muhingi, W. N., Mutavi, T., Kokonya, D., Simiyu, V. N., Musungu, B., Obondo, A., \& Kuria, M. W. (2015). Social Networks and Students' Performance in Secondary Schools: Lessons from an Open Learning Centre, Kenya. Journal of Education and Practice, 6(21), 171-177. Retrieved from https://eric.ed.gov/?id=EJ1079148

Nunnally, J. C. (1967). Psychometric Theory. New York, USA: McGraw Hill.

Ortega Barba, C. F., y Banderas Campero, A. (2011). Percepción de los jóvenes universitarios sobre el uso de Twitter en los procesos de enseñanzaaprendizaje. Revista Electrónica Apertura, 3(2), 1-20. http://www.udgvirtual.udg.mx/apertura/ index.php/apertura/article/view/203/0

Paschoal, T., Torres, C. V., y Porto, J. B. (2010). Felicidade no trabalho: relações com suporte organizacional e suporte social. Revista de Administração Contemporânea, 14(6), 1054-1072. https://doi.org/10.1590/
Pedrero Pérez, E., Ruiz Sánchez de León, J. Rojo Mota, G., Llanero Luque, M., Pedrero Aguilar, J., Morales Alonso, S., y Puerta García, C. (2017). Tecnologías de la Información y la Comunicación (TIC): abuso de Internet, videojuegos, teléfonos móviles, mensajería instantánea y redes sociales mediante el MULTICAGE-TIC. Adicciones, 30(1), 19-32. http://dx.doi.org/10.20882/adicciones.806

Ponce-Rojo, A., Hernández-Vega, L., HernándezContreras, J., y Fernández-Rodríguez,J. S. (2012). Análisis de contenido de las interacciones en línea en cursos de pregrado usando Facebook en una Learning. Sinéctica. Revista Electrónica de Educación, 39, 1-21. Recuperado de https:/l sinectica.iteso.mx/index.php/SINECTICA/ article/view/80

Posada, R., y Aguilar, O. (2012). La felicidad como elemento del desarrollo sostenible desde la organización. Revista del Centro de Investigación, 10(37), 83-94. https://doi. org/10.26457/recein.v10i37.106

Rodríguez, V., y Chapis, E. (2019). Importancia de las tecnologías de la información y las comunicaciones, el internet $y$ las redes sociales en el mejoramiento y desarrollo de las empresas. Revista Contribuciones a la Economía. Recuperado de https://eumed. net/rev/ce/2019/1/tecnologias-informacionempresas.html

Santos, M. (2010). Análisis de redes sociales y rendimiento académico: lecciones a partir del caso de los Estados Unidos. Debates En Sociología, (35). Recuperado de http://revistas. pucp.edu.pe/index.php/debatesensociologia/ article/view/2125

Santoveña-Casal, S., y Bernal-Bravo, C. (2019). Explorando la influencia del docente: Participación social en Twitter y percepción académica. Comunicar, (58), 75-84. https://doi. org/10.3916/C58-2019-07

Scuotto, V., Del Giudice, M., Peruta, M., \& Tarba, S. (2017). The performance implications of leveraging internal innovation through social media networks: An empirical verification of the smart fashion industry. Technological Forecasting and Social Change, 120,184-194. https://doi.org/10.1016/j.techfore.2017.03.021

Stankovska, G., Angelkovska, S., \& Grncarovska, S. (2016). Social Networks Use, Loneliness and Academic Performance among University Students. Bulgarian Comparative. Education Society, (14), 255-261. https://files.eric.ed.gov/ fulltext/ED568119.pdf 
Turel, O., \& Qahri-Saremi, H. (2016). Problematic Use of Social Networking Sites: Antecedents and Consequence from a Dual-System Theory Perspective. Journal of Management Information Systems, 33(4), 1087-1116. https://doi.org/10.10 80/07421222.2016.1267529

Urueña, A., Seco, J., Castro, R., y Cadenas, S. (2019). Perfil sociodemográfico de los internautas - Análisis de datos INE 2018. Madrid, España: Observatorio nacional de las telecomunicaciones y de la SI del Ministerio de Economía y Empresa de España. DOI: 10.30923/ PerSocInt-2018

Van Waes, S., De Maeyer, S., Moolenaar, N. M., Van Petegem, P., Van den Bossche, P. (2018). Strengthening networks: A social network intervention among higher education teachers. Learning and Instruction, 53, 3449. https://doi.org/https://doi.org/10.1016/j. learninstruc.2017.07.005

Wright, M. F. (2018). Cyberstalking Victimization, Depression, and Academic Performance: The Role of Perceived Social Support from Parents. CyberPsychology, Behavior \& Social Networking, 21(2), 110-116. https://doi. org/10.1089/cyber.2016.0742

Yan, L., Sallam, M. H., \& Yinghua, Y. (2019). The impact of WeChat use intensity and addiction on academic performance. Social Behavior \& Personality: An International Journal, 47(1), 1-7. https://doi.org/10.2224/sbp.7331

¿How to quote this article?

Ahumada-Tello, E., Ravina-Ripóll, R., \& Gálvez-Albarracín E. J. (2020). Social networks and academic performance self-perception in business sciences students. Cuadernos de Administración, 36(66), 105-117. https://doi.org/10.25100/cdea.v36i66.7761

Cuadernos de Administración journal by Universidad del Valle is under licence Creative Commons ReconocimientoNoComercial-SinObrasDerivadas 4.0. Based in http://cuadernosdeadministracion.univalle.edu.co/ 